\title{
Body Weight Test
}

National Cancer Institute

\section{Source}

National Cancer Institute. Body Weight Test. NCI Thesaurus. Code C119794.

A character or string that represents the long name of the body weight assessment. 